\title{
Phytotoxicity associated to microcystins: a review
}

\author{
Bittencourt-Oliveira, MC. ${ }^{a, b, c *}$, Hereman, TC. ${ }^{a, b}$, Cordeiro-Araújo, $M K^{a, c}$, \\ Macedo-Silva, I. ${ }^{b}$ Dias, CT. ${ }^{d}$, Sasaki, FFC. ${ }^{a}$ and Moura, AN. ${ }^{c}$

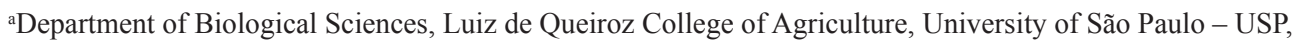 \\ Av. Pádua Dias, 11, CEP 13418-900, Piracicaba, SP, Brazil

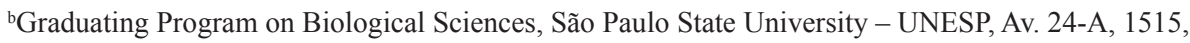 \\ CEP 13506-900, Rio Claro, SP, Brazil \\ ${ }^{\mathrm{c}}$ Graduating Program on Botany, Rural and Federal University of Pernambuco - UFRPE, Rua D. Manoel de Medeiros, \\ s/n, Dois Irmãos, CEP 52171-030, Recife, PE, Brazil \\ ${ }^{d}$ Departament of Exact Sciences, Luiz de Queiroz College of Agriculture, University of São Paulo - USP, \\ Av. Pádua Dias, 11, CEP 13418-900, Piracicaba, SP, Brazil \\ *e-mail:mbitt@usp.br
}

Received: April 23, 2013 - Accepted: September 20, 2013

\begin{abstract}
Microcystins (MC) are the most studied toxins of cyanobacteria since they are widely distributed and account for several cases of human and animal poisoning, being potent inhibitors of the serine/threonine protein phosphatases 1 (PP1) and 2A (PP2A). The phosphatases PP1 and PP2A are also present in plants, which may also suffer adverse effects due to the inhibition of these enzymes. In aquatic plants, biomass reduction is usually observed after absorption of cyanotoxins, which can bioaccumulate in its tissues. In terrestrial plants, the effects caused by microcystins vary from inhibition to stimulation as the individuals develop from seedling to adult, and include reduction of protein phosphatases 1 and 2A, oxidative stress, decreased photosynthetic activity and even cell apoptosis, as well as bioaccumulation in plant tissues. Thus, the irrigation of crop plants by water contaminated with microcystins is not only an economic problem but becomes a public health issue because of the possibility of food contamination, and this route of exposure requires careful monitoring by the responsible authorities.
\end{abstract}

Keywords: bioaccumulation, microcystins effects, crop plants, aquatic plants.

\section{Fitotocixidade associada às microcistinas: uma revisão}

\section{Resumo}

Microcistinas (MC) são as toxinas de cianobactérias mais estudadas, uma vez que são amplamente distribuídas e responsáveis por vários casos de intoxicação humana e animal. São potentes inibidoras das proteínas fosfatases serina/treonina 1 (PP1) e 2A (PP2A). As fosfatases PP1 e PP2A também estão presentes em plantas, as quais podem sofrer efeitos adversos devido à inibição dessas enzimas. Em plantas aquáticas, a redução da biomassa é geralmente observada após absorção de cianotoxinas que podem bioacumular em seus tecidos. Em plantas terrestres, os efeitos causados pelas microcistinas variam de inibição ao estímulo, como no desenvolvimento de plântulas ao estádio adulto, e incluem a redução de proteínas fosfatases 1 e 2A, estresse oxidativo, diminuição da atividade fotossintética e até mesmo apoptose celular, bem como a bioacumulação em tecidos de plantas. Assim, a irrigação de plantas cultivadas com água contaminada com microcistina não é apenas um problema econômico, mas torna-se um problema de saúde pública, devido à possibilidade de contaminação dos alimento, sendo uma via de exposição que requer um monitoramento cuidadoso por parte das autoridades responsáveis.

Palavras-chave: bioacumulação, efeitos de microcistinas, plantas da agricultura, plantas aquáticas.

\section{Introduction}

Microcystins (MCs) are toxins produced by cyanobacteria, photosynthetic microorganisms that preferentially inhabit aquatic environments. Since they are photosynthetic, these microorganisms release oxygen as a result of carbon dioxide fixation and, therefore, have an important role in the primary production of the ecosystems where they occur. Furthermore, some species have developed the ability to fix nitrogen through specialized cells called heterocysts (Wehr and Sheath, 2003). Consequently, cyanobacteria are extremely important for the incorporation of nitrogen 
into food chains. Cyanobacteria are widely distributed and can be found in terrestrial and aquatic environments, in endosymbiotic associations, and even in extreme habitats such as deserts, snow, inside rocks and in hot springs. However, most of the species are aquatic, being part of periphytic and phytoplanktonic communities in marine and freshwater environments (Komárek and Anagnostidis, 2005).

Microcystins are secondary metabolites produced by cyanobacteria populations of various species and genera, such as Microcystis Kützing ex Lemmermann, Anabaena Bory ex Bornet et Flahault, Anabaenopsis (Woloszynska) Miller, Hapalosiphon Nägeli ex Bornet et Flahault, Nostoc Vaucher ex Bornet et Flahault, Oscillatoria Vaucher ex Gomont, Planktothrix Anagnostidis et Komárek, among others (Carmichael, 1992; Sivonen and Jones, 1999). These metabolites are the most studied cianotoxins due to their wide distribution in the world and because of their toxicity to humans (Jochimsen et al., 1998; Chen et al., 2009; Giannuzzi et al., 2011), domestic animals (Wood et al., 2010), livestock (Orr et al., 2003), as well as organisms from the aquatic biota (Deblois et al., 2008; Lance et al., 2008).

The MCs are cyclic heptapeptides with D-alanine in position 1; D-erythro- $\beta$-methylaspartic acid (MeAsp) in position 3; 3-amino-9-methoxy-2,6,8-trimethyl-10phenyldeca-46-dienoic acid (ADDA) in position 5; D-glutamic acid in position 6; and N-methyl-dehydroalanine (Mdha) in position 7 (Dawson, 1998; Dietrich and Hoeger, 2005).

Among approximately 80 variants described, microcystinLR (MC-LR) with L-leucine in position 2 and L-arginine in position 4 , is the most studied, and is commonly recorded in blooming events of toxic cyanobacteria at concentrations between 0.1 and $10 \mu \mathrm{g} \mathrm{L}^{-1}$ (Zegura et al., 2011). Its $\mathrm{LD}_{50}$ is about $50 \mathrm{mg} \mathrm{Kg}^{-1}$ per intraperitoneal injection in mice (Chorus and Bartram, 1999). The amino acid Adda is regarded as the key component of the biological activity of microcystins (Carmichael, 1992). The second and fourth amino acid position may differ in the composition of L-amino acids, thereby generating a large variety of molecules.

The MCs are potent inhibitors of phosphatases of the serine/threonine protein 1 (PP1) and 2A (PP2A) (Mackintosh et al., 1990). Because these phosphatases are involved in the functional dynamics of hepatocystic cytoskeletons, their inhibition causes a disarrangement of the cell cytoskeleton, causing the death of these cells, leading to intrahepatic hemorrhage and sometimes causing death (Carmichael, 1992; Mackintosh et al., 1990; Wickstrom et al., 1995). Furthermore, the MCs may promote the appearance of tumors in the liver, thus having a carcinogenic character (Duy et al., 2000; Falconer, 1991).

Until the mid-1990s, few studies had been carried out on MCs. However, an incident in northeastern Brazil (Jochimsen et al., 1998), in which dozens of people died due to contamination by cyanotoxins in a hemodialysis procedure, encouraged studies in the area.

However, not only animals can be infected by these toxins. Plants also contain phosphatases PP1 and PP2A and, when in contact with MCs, may suffer adverse effects due to the inhibition of these enzymes.

\section{Effects of Microcystins on Aquatic Plants}

The harmful effects of microcystins on aquatic plants have been investigated due to the possibility of these organisms becoming exposed to cyanotoxins present in the surrounding water.

Biomass reduction in aquatic plants is usually observed after absorption of cyanotoxins, which can bioaccumulate in tissues (Mitrovic et al., 2005; Saqrane et al., 2007; Yin et al., 2005a).

It was observed in earlier studies reporting toxic effects in aquatic plants, a reduction in root length, dry mass and absorption of oxygen and nutrients on the macrophyte Phragmites australis (Cav.) Trin. ex Steudel, with allelopathic effects produced by a cyanobacterial bloom where the cyanobacteria Microcystis predominated (Yamasaki, 1993).

Allelopathy is any direct or indirect effect, beneficial or harmful, produced by plants and microorganisms on another plant after the release of chemicals into the environment (Rice, 1984). A decrease in the production of both photosynthetic oxygen and chlorophyll $a$ and $b$ content, as well as growth inhibition of Ceratophyllum demersum L. and Myriophyllum spicatum L. exposed to concentrations of 0.1 to $5 \mathrm{mg} \mathrm{L}^{-1}$ of MC-LR, showed that this toxin may have a possible allelopathic action (Pflugmacher, 2002).

A decrease in the growth of Vallisneria natans (Lour.) Hara was observed after the absorption of MC-RR by seeds and seedlings exposed to a concentration 10-10,000 $\mathrm{mg} \mathrm{L}^{-1}$ for thirty days, with differential accumulation and a dose-dependent relationship between the roots $(0.6$ to $14,800 \mathrm{mg} \mathrm{Kg}^{-1}$ fresh mass) and leaves (0.3 to $300 \mathrm{mg}$ $\mathrm{Kg}^{-1}$ fresh mass) (Yin et al., 2005a). In Lemna minor L. and Wolffia arrhiza (L.) Horkel. ex Wimm, besides a decrease in growth, an increase in activity of the enzyme peroxidase was observed after exposure, for five days, to concentrations of 10,000 to $20,000 \mathrm{mg} \mathrm{L}^{-1} \mathrm{MC}-\mathrm{LR}$ (Mitrovic et al., 2005). There was in this case a positive correlation between the concentration of microcystins applied and found in the tissues of L. minor.

Oxidative stress during biotransformation of MC-LR via glutathione conjugate can be caused by an increase in the activity of antioxidant enzymes and glutathione content (GSH) in C. demersum when exposed to $5 \mathrm{mg}$ $\mathrm{L}^{-1}$ of MC-LR (Pflugmacher, 2004). After evaluating the activity of the enzyme glutathione S-transferase (GST), a possible metabolic detoxification was verified, similar to that occurring in toxic substances (xenobiotics) (Pflugmacher et al., 1998).

A histological study on tissue culture of $P$. australis exposed to concentrations of MC-LR between 2,500$40,000 \mathrm{mg} \mathrm{L}^{-1}$ showed greater damage in the roots due to the obliteration of aerenchyma by callus material (Máthé et al., 2007). 
There was a reduction in growth, chlorophyll $a$ and $b$ content and oxidative stress in Lemna gibba L. grown for twelve days in culture medium containing MC-RR and MC-WR at concentrations between 75 and $300 \mathrm{mg} \mathrm{L}^{-1}$. Bioaccumulation of toxins was observed in plant tissues. MC-RR and another unknown variant were detected in the fresh mass indicating a possible degrading metabolism of the plant toxin (Saqrane et al., 2007).

Studies on the effects of MC-LR in the organization of microtubules and chromatin in root cells of $P$. australis demonstrated that the induction of abnormal mitotic cells coincided with concentrations where inhibition of protein phosphatases was greater than $50 \%\left(>500 \mathrm{mg} \mathrm{L}^{-1}\right)$ (Máthé et al., 2009).

\section{Diverse Effects of Microcystins on Terrestrial Plants}

There is a possibility that terrestrial plants, particularly those of the human diet, could be contaminated by cyanotoxins contained in irrigation water. Such a possibility motivated researchers to evaluate cyanotoxins effects on these organisms, paying particular attention to microcystins.

The effects of microcystins on terrestrial plants have also been linked to the enzymatic activities of these plants. One example of this effect was a decrease in the activities of phosphatase proteins 1 (PP1) and 2A (PP2A) in Brassica napus L. when exposed to MC-LR (Mackintosh et al., 1990). There was also a reduction in the activity of the enzyme sucrose-phosphate synthase resulting from the inhibition of PP1 and PP2A by okadaic acid and MC-LR in leaves of Spinacia oleracea L., both in vitro and in vivo, causing a decrease in the biosynthesis of sucrose and the fixation of carbon dioxide (Siegl et al., 1990).

The cultivation of cells of Arabidopsis thaliana (L.) Heynh, exposed to antioxidant enzyme activity at 10, 100, 1,000 and 5,000 $\mathrm{mg} \mathrm{L}^{-1}$ of MC-RR for $24 \mathrm{~h}$ and $48 \mathrm{~h}$, showed oxidative stress in the two highest concentrations for the longest exposure (Yin et al., 2005b). Responses to oxidative stress when increasing the activity of antioxidant enzymes were also observed in seedlings of Lepidium sativum L. exposed to commercial MC-LR and an extract of $M$. aeruginosa with $0.5 \mathrm{mg} \mathrm{L}^{-1}$ of total $\mathrm{MC}$, containing MC-LR and MC-RR (Stüven and Pflugmacher, 2007).

Brassica chinensis L. and B. napus plants grown under various concentrations of MCs (equivalent to 0.008 to $4 \mathrm{mg}$ $\mathrm{L}^{-1} \mathrm{MC}-\mathrm{LR}$ ) for seven days displayed inhibition of growth and development. In this study, activities of superoxide dismutase (SOD), peroxidase (POD) and catalase (CAT) demonstrated that exposure to $\mathrm{MC}$ manifested itself in the form of oxidative stress (Xue et al., 2010).

El Khalloufi et al. (2011) evaluated the effects of different concentrations of MCs on the development of symbiosis between Medicago sativa L. and rhizobia strains and observed a reduction in growth of both the plant and the bacterial nodules. It was also found that exposure of alfalfa seeds and seedlings to concentrations of $0,2.22$,
11.12 or $22.24 \mathrm{mg} \mathrm{L}^{-1}$ MCs affected all stages of plant development and led to reduced root length.

Effects of microcystins on protein phosphatases were found in Medicago sativa L. Exposure of plants grown in garden soil and treated with $4 \mathrm{~mL}$ every other day for a week at a concentration of $5 \mathrm{mg} \mathrm{L}^{-1} \mathrm{MC}-\mathrm{LR}$ led to a reduction in the activity of PP1 and PP2A (Peuthert et al., 2008). Slightly lower inhibition was obtained with $M$. aeruginosa cell extract containing $5 \mathrm{mg} \mathrm{L}^{-1}$ of MC-LR, while no inhibition was obtained with Synechocystis spp. (no microcystinproducing) cell extract.

Other effects of microcystins on terrestrial plants have also been evaluated for photosynthesis. These effects have demonstrated, for example, reduction in the net rate of photosynthesis in the leaves of Phaseolus vulgaris L. exposed to 10,000 and $100,000 \mathrm{mg} \mathrm{L}^{-1}$. It was observed, in this same study, a greater inhibitory effect following topical application of an aqueous solution containing MC-LR and multiple applications at lower concentrations (Abe et al., 1996).

The observation of multiple effects of microcystins, such as reduction in growth, productivity, activity of photosystem II and increase in the accumulation of nutrients in the plant roots of P. sativum L., Lens esculenta Moench, Zea mays L. and Triticum durum L., has been increasingly frequent. Saqrane et al. (2009) observed that plants, irrigated every third day for thirty days with the crude extract from bloom cells containing six variants of microcystin at concentrations of 500, 1,050 and 4,200 $\mathrm{mg} \mathrm{L}^{-1}$, accumulated different amounts of the toxin in their organs.

In six varieties of Spinacia oleracea L. grown in garden soil for six weeks, irrigated twice a week with $50 \mathrm{~mL}$ of aqueous cell-free extract containing $0.5 \mathrm{mg} \mathrm{L}^{-1}$ of $\mathrm{MC}$ $\mathrm{LR}$, a reduction in growth, production of photosynthetic oxygen, chlorosis and oxidative stress was observed (Pflugmacher et al., 2007).

\section{Inhibitory Effects on Seeds, Seedlings and Young Plants}

Seeds, seedlings and young plants show substantial sensitivity to microcystins. The growth of Synapis alba L. seedlings was inhibited when exposed for eight days at concentrations between 100 and $100,000 \mathrm{mg} \mathrm{L}^{-1}$ of microcystins, with $\mathrm{LD}^{50}$ value of $3000 \mathrm{mg} \mathrm{L}^{-1}$ and they were thus indicated for bioassays (Kós et al., 1995). Likewise, the cultivation of $S$. alba seeds for seven days in solidified nutrient medium containing concentrations of purified MCs between 500 and 40,000 $\mathrm{mg} \mathrm{L}^{-1}$ showed inhibitory effects on seedling development. For MC-RR there was a dose-dependent reduction in seedling length and activity of PP1 and PP2A, LD ${ }_{50}$ value of $800 \mathrm{mg} \mathrm{L}^{-1}$. Moreover, the absorption of MC-LR was also dose-dependent, and a concentration of $5.3 \mathrm{mg} \mathrm{Kg}^{-1}$ of fresh mass was found in seedlings with healthy appearance (Kurki-Helasmo and Meriluoto, 1998).

Seeds of L. sativum seem to be more sensitive to low concentrations of toxin, after exposure for six days at 
$10 \mathrm{mg} \mathrm{L}^{-1}$ of MC-LR, or to cell-free extract containing 1 or $10 \mathrm{mg} \mathrm{L}^{-1} \mathrm{MC}-\mathrm{LR}$ (Gehringer et al., 2003).

Significant differences were observed in phytotoxic effects on plants of Solanum tuberosum L., S. alba and P. vulgaris, when exposed to variants of MC (MC-RR, MC- LR and MC-LF), being MC-RR the most lethal (McElhiney et al., 2001). The anthocyanin content and the activity of the single-stranded DNase enzyme (sDNAse) in seeds of $S$. alba, germinated on filter paper moistened with MC-LR concentrations between 3,500 and 30,000 $\mathrm{mg} \mathrm{L}^{-1}$ showed values indicative of physiological changes. A reduction in the length and dry mass of the seedlings was observed, with $\mathrm{LD}_{50}$ value of $19,900 \mathrm{mg} \mathrm{L}^{-1}$ for those germinated in photoperiod and $\mathrm{LD}_{50}$ value of $14,700 \mathrm{mg} \mathrm{L}^{-1}$ for those germinated in the dark (M-Hamvas et al., 2003).

Exposure of seeds of $O$. sativa and B. napus to different concentrations of cell-free extract, containing three variants of microcystin (MC-LR, MC-RR and MC-YR) for ten days at concentrations between 24 and $3000 \mathrm{mg} \mathrm{L}^{-1}$, caused phytotoxic effects mainly on $B$. napus, which had the lowest germination and dry mass percentages (Chen et al., 2004). The accumulation of toxin in plant tissues was dosedependent, with a maximum of $0.651 \mathrm{mg} \mathrm{g}^{-1}$ of fresh mass.

Seedlings of Brassica oleracea var. italica Plenck and $S$. alba were grown in vermiculite soil (60:40, v/v) and irrigated with water containing microcystin concentrations of 1 and $10 \mathrm{mg} \mathrm{L}^{-1}$. Slight growth inhibition (10\%) was observed for B. oleracea var. italica. Through mass spectrometry, only MC-LR was detected in the roots of the plants at concentrations of 900 to $2,600 \mathrm{mg} \mathrm{g}^{-1}$ fresh mass (Järvenpää et al., 2007).

Through the germination of seeds of Pisum sativum L., L. esculenta, Z. mays and T. durum in filter paper soaked with cell-free extract containing MC-LR at concentrations between 1,600-11,600 $\mathrm{mg} \mathrm{L}^{-1}$, a dose-dependent relationship was observed in both germination inhibition and length decrease of the epicotyl and primary root as well as in the number of lateral roots due to abnormalities caused to the pericycle. Furthermore, the damage was irreversible to the most sensitive species ( $P$. sativum) and reversible to the least sensitive (L. esculenta) (Saqrane et al., 2008).

Increase in the germination speed of B. napus and Brassica chinensis L. seeds was observed after exposure to low concentrations of cell-free extract from blooms containing MC-RR ( 1 and $10 \mathrm{mg} \mathrm{L}^{-1}$ ). In this same material, reduction was observed at higher concentrations (100 and $1,000 \mathrm{mg} \mathrm{L}^{-1}$ ), the degree of inhibition varying according to the stage of plant life, with younger individuals and those with longer exposure time being the most affected (Bibo et al., 2008).

Effects of extracts of Microcystis aeruginosa strains (microcystin producing and non-producing) during germination and root growth of grasses (Festuca rubra L. and Lolium perenne L.) and lettuce (L. sativa) were evaluated (Pereira et al., 2009). A clear inhibition of root growth in L. sativa exposed to strains containing microcystins ( 5.9 to $56.4 \mathrm{mg} \mathrm{L}^{-1}$ ) was observed. However, the lineage that produced the most pronounced effects contained the lowest concentration of microcystins, suggesting that other compounds may also affect cell growth. Seed germination was not affected in any of the plants studied.

Alkylbenzene sulfonate (LAS), an anionic surfactant, widely used for industrial and domestic applications, and MC-LR are widely distributed in terrestrial and aquatic ecosystems, but their combined ecotoxicological effects were unknown (Wang et al., 2011). After investigation of the toxic effects of MC-LR, LAS and their mixture in L. sativa, and after evaluating the degree of accumulation of MC-LR in lettuce with or without LAS, Wang et al. (2011) observed changes in seed germination and aerial root growth, where seedling growth was more sensitive than germination in toxic exposure. These results suggest that there is a synergistic interaction between MC-LR and LAS.

\section{Accumulation of Microcystins in Plant Tissues}

It is known that natural contact between terrestrial plants and microcystins is rare. However, there are many studies reporting the effects of various concentrations of microcystin, both on the development of some plants and on the accumulation of leaf tissue (Codd et al., 1999; Crush et al., 2008). The uprising of this information was possible because an important contamination pathway, otherwise neglected, has been taken into account by researchers, that is, plant irrigation with contaminated water. Irrigation of several crop plants, including vegetables, may lead to lower production levels, as well as to human contamination through consumption (Chen et al., 2004).

Codd et al. (1999) verified the presence of microcystins and individual cells and colonies of $M$. aeruginosa in leaves of L. sativa ten days after the last irrigation with water containing the toxin-producing cyanobacteria. Subsequently, Crush et al. (2008) observed the contamination of L. sativa when irrigated with water containing microcystin at a concentration of $1,700 \mathrm{mg} \mathrm{L}^{-1}$ for ten days, with a risk of ingestion of $3.3 \mathrm{mg}$ when consuming $40 \mathrm{~g}$ of salad. Hereman and Bittencourt-Oliveira (2012) observed contamination of L. sativa irrigated at a lower concentration, similar to natural concentrations between 0.62 to $12.5 \mathrm{mg} \mathrm{L}^{-1}$, with a risk of ingestion of 0.33 to $7.11 \mathrm{mg}$, which could exceed the daily tolerable value of $0.04 \mathrm{mg} \mathrm{Kg}^{-1}$ of body mass/ day recommended by the World Health Organization (WHO, 1998).

Other species of significant economic and dietary importance were assessed. In seedlings of eleven species (Glycine max (L.) Merril, P. vulgaris, Z. mays, among others) grown on solidified medium exposed to MC-LR and LF and cell-free extract containing MC-LR, for 24 hours at a concentration of $5 \mathrm{mg} \mathrm{L}^{-1}$, presented bioaccumulation in their roots (12 to $127 \mathrm{mg} \mathrm{Kg}^{-1}$ fresh mass) higher than in their stems (1.0 to $64 \mathrm{mg} \mathrm{Kg}^{-1}$ fresh mass) (Peuthert et al., 2007). A correlation of bioaccumulation with measured cellular damage was found due to lipid peroxidation.

The method of application of the toxin interferes with its absorption. When $100 \mathrm{~mL}$ of crude extract from blooms containing $1,700 \mathrm{mg} \mathrm{L}^{-1}$ of ten variants of microcystin 
(mainly MC-RR and MC-LR) was applied directly into the root or aerial part of L. sativa, B. napus, Lolium perenne L. and Trifolium repens L. grown in sand, for three or six days, Crush et al. (2008) found differences in bioaccumulation (values between 550 and 3,330 $\mathrm{mg} \mathrm{Kg}^{-1}$ dry mass). The toxin was not found in the leaves when applied directly into the root, indicating an absence of translocation of the molecule.

The use of groundwater can also lead to contamination. In horticulture plants, such as radish (Raphanus sativum L.), lettuce (L. sativa), arugula (Eruca sativa L.), cabbage (Brassica oleracea L.) and parsley (Petroselinum crispum (Mill.) Nym.) irrigated with groundwater contaminated with MC-YR (Mohamed and Al-Shehri, 2009), concentrations ranging from 0.07 to $1.2 \mathrm{mg} \mathrm{g}^{-1}$ fresh mass accumulated in the roots and leaves were measured. The plants did not show any morphological and physiological changes or growth inhibition. According to the authors of this study, the concentrations found in groundwater MCs were not high enough to cause effects on plants; however, these values should not be discarded when considering human consumption.

Recently, Chen et al. (2012) evaluated the accumulation of microcystins at low concentrations (10 to $200 \mathrm{mg} \mathrm{L}^{-1}$ ) in grains of $O$. sativa in a natural environment with irrigation water from Lake Taihu, China. Twenty-one out of the 44 studied samples showed bioaccumulation of MC-LR. However, according to the authors, the amount of MC-LR accumulated in grains may not represent a threat to human health, as the daily tolerable value of contaminated rice grains $(0.2-0.4 \mathrm{Kg})$ for a person weighing $60 \mathrm{Kg}$ is around $1.47 \mathrm{mg}$, which would represent approximately $0.04 \mathrm{mg}$ $\mathrm{Kg}^{-1}$ per kilo of body mass. Thus, the tolerance of daily intake of this food complies with the recommendations of the World Health Organization.

In fruit trees such as apple (Malus pumila Mill.), bioaccumulation of microcystins in their tissues, as well as harmful effects, were caused by in vitro exposure to crude extracts of MC-LR-producing M. aeruginosa (Chen et al., 2010). After exposure to MCs (above $0.3 \mathrm{mg} \mathrm{mL}^{-1}$ ), growth and proliferation of shoots of M. pumila decreased dramatically. Additionally, after 14 days of exposure to 3 $\mathrm{mg} \mathrm{mL}^{-1}$ of microcystin, the plant accumulated an amount equivalent to $36.45 \mathrm{ng} \mathrm{g}^{-1}$ day.

Exposure to cyanotoxins by humans through different routes is a matter of serious concerns by worldwide authorities. The current legislation of different countries usually considers the recommendations given by the World Health Organization (WHO) about the risks of contamination and limits of acceptable concentrations of cyanotoxins, both in drinking water and in the daily intake by any other route. Consumption by humans of food contaminated with cyanotoxins could be an exposure route that has not been given enough attention.

Generally, there are various effects caused by microcystins on plants. According to Babica et al. (2006), one must consider that the effects observed in most studies are achieved at much higher concentrations than those commonly found in nature $\left(<10 \mu \mathrm{g} \mathrm{L}{ }^{-1}\right)$. This could indicate that the action of microcystins as allelopathic compounds on photoautotrophic competitor organisms has a low probability. However, according to Leflaive and Ten-Hage (2007), based on evolutionary, ecological and physiological aspects, at least some toxins, including microcystins, demonstrate allelopathic characteristics over photoautotrophic competitors.

It still requires much more studies to conclude if, or if not, cyanotoxins cause allelopathic functions. This is an issue demanding, therefore, a carefull data analysis and interpretation. The production of cyanotoxin itself has been indicated as necessary for the functional part of the cyanobacteria metabolism.

\section{Conclusions}

Studies have shown that phytotoxicity of microcystins interferes with metabolism and biomass of aquatic and terrestrial plants, causin reduction of protein phosphatases 1 and $2 \mathrm{~A}$, oxidative stress, decrease in photosynthetic activity and even apoptosis.

Sensitivity occurs in seeds and seedlings, and even in mature plants, in which the root is usually the most affected organ because of its greater contact with microcystins. Therefore, damage is generally more extensive with greater exposure time and concentration of the toxin.

Exposing crops grown to microcystins contaminated water is an issue beyond mere economic damages. The possibility of food contamination is, by far and large, a matter of public health requiring, therefore, a severe monitoring of this exposure pathway by the government officers.

\section{References}

ABE, T., LAWSON, T., WEYERS, JDB. and CODD, GA., 1996. Microcystin-LR inhibits photosynthesis of Phaseolus vulgaris primary leaves: implications for current spray irrigation practice. The New Phytologist, vol. 133, no. 4, p. 651-658. http://dx.doi. org/10.1111/j.1469-8137.1996.tb01934.x.

BABICA, P., BLÁHA, L. and MARSÁLEK, B., 2006. Exploring the natural role of microcystins - a review of effects on photoautotrophic organisms. Journal of Phycology, vol. 42, no. 1, p. 9-20. http:// dx.doi.org/10.1111/j.1529-8817.2006.00176.x.

BIBO, L., YAN, G., BANGDING, X., JIANTONG, L. and YONGDING, L., 2008. A laboratory study on risk assessment of microcystin-RR in cropland. Journal of Environmental Management, vol. 86, no. 3, p. 566-574. http://dx.doi.org/10.1016/j. jenvman.2006.12.040. PMid:17467149

CARMICHAEL, WW., 1992. Cyanobacteria secondary metabolitesthe cyanotoxins. The Journal of Applied Bacteriology, vol. 72, no. 6, p. 445-459. http://dx.doi.org/10.1111/j.1365-2672.1992. tb01858.x. PMid: 1644701

CHEN, J., SONG, L., DAI, J., GAN, N. and LIU, Z., 2004. Effects of microcystins on the growth and the activity of superoxide dismutase and peroxidase of rape (Brassica napus L.) and rice (Oryza sativa L.). Toxicon, vol. 43, no. 4, p. 393-400. http://dx.doi. org/10.1016/j.toxicon.2004.01.011. PMid:15051402 
CHEN, J., XIE, P., LI, L. and XU, J., 2009. First identification of the hepatotoxic microcystins in the serum of a chronically exposed human population together with indication of hepatocellular damage. Toxicological sciences: an official journal of the Society of Toxicology, vol. 108, no. 1, p. 81-89. http://dx.doi.org/10.1093/ toxsci/kfp009. PMid:19151163

CHEN, J., DAI, J., ZHANG, H., WANG, C., ZHOU, G., HAN, Z. and LIU, Z., 2010. Bioaccumulation of microcystin and its oxidative stress in the apple (Malus pumila). Ecotoxicology (London, England), vol. 19, no. 4, p. 796-803. http://dx.doi. org/10.1007/s10646-009-0456-5. PMid:20052542

CHEN, J., HAN, FX., WANG, F., ZHANG, H. and SHI, Z., 2012. Accumulation and phytotoxicity of microcystin-LR in rice (Oryza sativa). Ecotoxicology and Environmental Safety, vol. 76, no. 2, p. 193-199. http://dx.doi.org/10.1016/j.ecoenv.2011.09.022. PMid:22036264

CHORUS, I. and BARTRAM, J. (Eds.), 1999. Toxic cyanobacteria in water: a guide to their public health consequences, monitoring and management. London: E \& FN Spon. 416 p. http://dx.doi. org/10.4324/9780203478073

CODD, GA., METCALF, JS. and BEATTIE, KA., 1999. Retention of Microcystis aeruginosa and microcystin by salad lettuce (Lactuca sativa) after spray irrigation with water containing cyanobacteria. Toxicon, vol. 37, no. 8, p. 1181-1185. http://dx.doi.org/10.1016/ S0041-0101(98)00244-X. PMid:10400301

CRUSH, JR., BRIGGS, LR., SPROSEN, JM. and NICHOLS, SN., 2008. Effect of irrigation with lake water containing microcystins on microcystin content and growth of ryegrass, clover, rape, and lettuce. Environmental Toxicology, vol. 23, no. 2, p. 246-252. http://dx.doi.org/10.1002/tox.20331. PMid:18214908

DAWSON, RM., 1998. The toxicology of microcystins. Toxicon, vol. 36, no. 7, p. 953-962. http://dx.doi.org/10.1016/S00410101(97)00102-5. PMid:9690788

DEBLOIS, CP., ARANDA-RODRIGUEZ, R., GIANI, A. and BIRD, DF., 2008. Microcystin accumulation in liver and muscle of tilapia in two large Brazilian hydroelectric reservoirs. Toxicon, vol. 51, no. 3, p. 435-448. http://dx.doi.org/10.1016/j. toxicon.2007.10.017. PMid:18067935

DIETRICH, D. and HOEGER, S., 2005. Guidance values for microcystins in water and cyanobacterial supplement products (blue-green algal supplements): a reasonable or misguided approach? Toxicology and Applied Pharmacology, vol. 203, no. 3, p. 273-289. http://dx.doi.org/10.1016/j.taap.2004.09.005. PMid:15737681

DUY, TN., LAM, PKS., SHAW, GR. and CONNELL, DW., 2000. Toxicology and risk assessment of freshwater cyanobacterial (blue-green algal) toxins in water. Reviews of Environmental Contamination and Toxicology, vol. 163, p. 113-185. http://dx.doi. org/10.1007/978-1-4757-6429-1 3. PMid:10771585

EL KHALLOUFI, F., OUFDOU, K., LAHROUNI, M., EL GHAZALI, I., SAQRANE, S., VASCONCELOS, V. and OUDRA, B., 2011. Allelopatic effects of cyanobacteria extracts containing microcystins on Medicago sativa-Rhizobia symbiosis. Ecotoxicology and Environmental Safety, vol. 74, no. 3, p. 431-438. http://dx.doi. org/10.1016/j.ecoenv.2010.10.006. PMid:21030085

FALCONER, IR., 1991. Tumor promotion and liver injury caused by oral consumption of cyanobacteria. Environmental Toxicology and Water Quality, vol. 6, no. 2, p. 177-184. http:// dx.doi.org/10.1002/tox.2530060207.
GEHRINGER, MM., KEWADA, V., COATES, N. and DOWNING, TG., 2003. The use of Lepidium sativum in a plant bioassay system for the detection of microcystin-LR. Toxicon, vol. 41, no. 7, p. 871-876. http://dx.doi.org/10.1016/S0041-0101(03)00049-7. PMid:12782087

GIANNUZZI, L., SEDAN, D., ECHENIQUE, R. and ANDRINOLO, D., 2011. An acute case of intoxication with cyanobacteria and cyanotoxins in recreational water in Salto Grande Dam, Argentina. Marine Drugs, vol. 9, no. 11, p. 2164-2175. http:// dx.doi.org/10.3390/md9112164. PMid:22163179

HEREMAN, TC. and BITTENCOURT-OLIVEIRA, MC., 2012. Bioaccumulation of microcystins in lettuce. Journal of Phycology, vol. 48, no. 6, p. 1535-1537. http://dx.doi.org/10.1111/jpy.12006.

JÄRVENPÄÄ, S., LUNDBERG-NIINISTÖ, C., SPOOF, L., SJÖVALL, O., TYYSTJÄRVI, E. and MERILUOTO, J., 2007. Effects of microcystins on broccoli and mustard, and analysis of accumulated toxin by liquid chromatography-mass spectrometry. Toxicon, vol. 49, no. 6, p. 865-874. http://dx.doi.org/10.1016/j. toxicon.2006.12.008. PMid: 17275870

JOCHIMSEN, EM., CARMICHAEL, WW., AN, JS., CARDO, DM., COOKSON, ST., HOLMES, CEM., ANTUNES, MBC., DE MELO FILHO, DA., LYRA, TM., BARRETO, VS., AZEVEDO, SMFO. and JARVIS, WR., 1998. Liver failure and death after exposure to microcystins at a hemodialysis center in Brazil. The New England Journal of Medicine, vol. 338, no. 13, p. 873-878. http://dx.doi.org/10.1056/NEJM199803263381304. PMid:9516222

KOMÁREK, J. and ANAGNOSTIDIS, K., 2005. Cyanoprokaryota II. Teil Oscillatoriales. In BÜDEL, B., KRIENITZ, L., GÄRTNER, G. and SCHAGERL, M. (Eds.). Süßwasserflora von Mitteleuropa. Munchen: Elsevier Gmbh.

KÓS, P., GORZÓ, G., SURÁNYI, G. and BORBÉLY, G., 1995. Simple and efficient method for isolation and measurement of cyanobacterial hepatotoxins by plant tests (Sinapis alba L.). Analytical Biochemistry, vol. 225, no. 1, p. 49-53. http://dx.doi. org/10.1006/abio.1995.1106. PMid:7778786

KURKI-HELASMO, K. and MERILUOTO, J., 1998. Microcystin uptake inhibits growth and protein phosphatase activity in mustard (Sinapis alba L.) seedlings. Toxicon, vol. 36, no. 12, p. 1921-1926. http://dx.doi.org/10.1016/S0041-0101(98)00114-7. PMid:9839676

LANCE, E., BUGAJNY, E., BORMANS, N. and GÉRARD, C., 2008. Consumption of toxic cyanobacteria by Potamopyrgus antipodarum (Gastropoda, Prosobranchia) and consequences on life traits and microcystin accumulation. Harmful Algae, vol. 7, no. 4, p. 464-472. http://dx.doi.org/10.1016/j.hal.2007.10.004.

LEFLAIVE, J. and TEN-HAGE, L., 2007. Algal and cyanobacterial secondary metabolites in freshwaters: a comparison of allelopathic compounds and toxins. Freshwater Biology, vol. 52, no. 2, p. 199-214. http://dx.doi.org/10.1111/j.1365-2427.2006.01689.x.

MACKINTOSH, C., BEATTIE, KA., KLUMPP, S., COHEN, P. and CODD, GA., 1990. Cyanobacterial microcystin-LR is a potent and specific inhibitor of protein phosphatases 1 and $2 \mathrm{~A}$ from both mammals and higher plants. FEBS Letters, vol. 264, no. 2, p. 187-192. http://dx.doi.org/10.1016/0014-5793(90)80245-E. PMid:2162782

MCELHINEY, J., LAWTON, LA. and LEIFERT, C., 2001. Investigations into the inhibitory effects of microcystins on plant growth, and the toxicity of plant tissues following exposure. Toxicon, vol. 39, no. 9, p. 1411-1420. http://dx.doi.org/10.1016/ S0041-0101(01)00100-3. PMid:11384731 
MÁTHÉ, C., M-HAMVAS, M., VASAS, G., SURÁNYI, G., BÁCSI, I., BEYER, D., TÓTH, S., TÍMÁR, M. and BORBÉLY, G., 2007. Microcystin-LR, a cyanobacterial toxin, induces growth inhibition and histological alterations in common reed (Phragmites australis) plants regenerated from embryogenic calli. New Phytologist, vol. 176, no. 4, p. 824-835. http://dx.doi. org/10.1111/j.1469-8137.2007.02230.x. PMid:17924947

MÁTHÉ, C., BEYER, D., ERDÖDI, F., SERFÖZÖ, Z., SZÉKVÖLGYI, L., VASAS, G., M-HAMVAS, M., JÁMBRIK, K., GONDA, S., KISS, A., SZIGETI, ZM. and SURÁNYI, G., 2009. Microcystin-LR induces abnormal root development by altering microtubule organization in tissue-cultured common reed (Phragmites australis) plantlets. Aquatic Toxicology (Amsterdam, Netherlands), vol. 92, no. 3, p. 122-130. http://dx.doi.org/10.1016/j. aquatox.2009.02.005. PMid:19269700

M-HAMVAS, M., MÁTHÉ, C., MOLNÁR, E., VASAS, G., GRIGORSZKY, I. and BORBELY, G., and the M-HAMVAS, 2003. Microcystin-LR alters the growth, anthocyanin content and single-stranded DNase enzyme activities in Sinapis alba L seedlings. Aquatic Toxicology, vol. 62, no. 1, p. 1-9. http:// dx.doi.org/10.1016/S0166-445X(01)00273-9. PMid:12413789

MITROVIC, SM., ALLIS, O., FUREY, A. and JAMES, KJ., 2005. Bioaccumulation and harmful effects of microcystinLR in the aquatic plants Lemna minor and Wolffia arrhiza and the filamentous alga Chladophora fracta. Ecotoxicology and Environmental Safety, vol. 61, no. 3, p. 345-352. http://dx.doi. org/10.1016/j.ecoenv.2004.11.003. PMid:15922800

MOHAMED, ZA. and AL SHEHRI, AMA., 2009. Microcystins in groundwater wells and their accumulation in vegetable plants irrigated with contaminated waters in Saudi Arabia. Journal of Hazardous Materials, vol. 172, no. 1, p. 310-315. http://dx.doi. org/10.1016/j.jhazmat.2009.07.010. PMid:19640645

ORR, PT., JONES, GJ., HUNTER, RA. and BERGER, K., 2003. Exposure of beef cattle to sub-clinical doses of Microcystis aeruginosa: toxin bioaccumulation, physiological effects and human health risk assessment. Toxicon, vol. 41, no. 5, p. 613-620. http:// dx.doi.org/10.1016/S0041-0101(03)00006-0. PMid:12676440

PEREIRA, S., SAKER, ML., VALE, M. and VASCONCELOS, VM., 2009. Comparison of sensitivity of grasses (Lolium perenne L. and Festuca rubra L.) and lettuce (Lactuca sativa L.) exposed to water contaminated with microcystins. Bulletin of Environmental Contamination and Toxicology, vol. 83, no. 1, p. 81-84. http:// dx.doi.org/10.1007/s00128-009-9763-z. PMid:19436926

PEUTHERT, A., CHAKRABARTI, S. and PFLUGMACHER, S., 2007. Uptake of microcystins-LR and -LF (cyanobacterial toxins) in seedlings of several important agricultural plant species and the correlation with cellular damage (lipid peroxidation). Environmental Toxicology, vol. 22, no. 4, p. 436-442. http:// dx.doi.org/10.1002/tox.20266. PMid:17607734

PEUTHERT, A., LAWTON, L. and PFLUGMACHER, S., 2008. In vivo influence of cyanobacterial toxins on enzyme activity and gene expression of protein phosphatases in Alfalfa (Medicago sativa). Toxicon, vol. 52, no. 1, p. 84-90. http://dx.doi.org/10.1016/j. toxicon.2008.04.172. PMid:18620722

PFLUGMACHER, S., WIEGAND, C., OBEREMM, A., BEATTIE, KA., KRAUSE, E., CODD, GA. and STEINBERG, CEW., 1998. Identification of an enzymatically formed glutathione conjugate of the cyanobacterial hepatotoxin microcystin-LR: the first step of detoxication. Biochimica et Biophysica Acta, vol. 1425, no. 3, p. 527-533. http://dx.doi.org/10.1016/S0304-4165(98)00107-X. PMid:9838216
PFLUGMACHER, S., 2002. Possible allelopathic effects of cyanotoxins, with reference to microcystin-LR, in aquatic ecosystems. Environmental Toxicology, vol. 17, no. 4, p. 407-413. http://dx.doi.org/10.1002/tox.10071. PMid:12203964

PFLUGMACHER, S., 2004. Promotion of oxidative stress in the aquatic macrophyte Ceratophyllum demersum during biotransformation of the cyanobacterial toxin microcystin-LR. Aquatic Toxicology (Amsterdam, Netherlands), vol. 70, no. 3, p. 169-178. http://dx.doi.org/10.1016/j.aquatox.2004.06.010. PMid:15550274

PFLUGMACHER, S., AULHORN, M. and GRIMM, B., 2007. Influence of a cyanobacterial crude extract containing microcystinLR on the physiology and antioxidative defence systems of different spinach variants. New Phytologist, vol. 175, no. 3, p. 482-489. http://dx.doi.org/10.1111/j.1469-8137.2007.02144.x. PMid: 17635223

RICE, EL., 1984. Allelopathy. 2nd ed. New York: Academic Press.

SAQRANE, S., GHAZALI, IE., OUAHID, Y., HASSNI, ME., HADRAMI, IE., BOUARAB, L., DEL CAMPO, FF., OUDRA, B. and VASCONCELOS, V., 2007. Phytotoxic effects of cyanobacteria extract on the aquatic plant Lemna gibba: microcystin accumulation, detoxication and oxidative stress induction. Aquatic Toxicology (Amsterdam, Netherlands), vol. 83, no. 4, p. 284-294. http://dx.doi. org/10.1016/j.aquatox.2007.05.004. PMid:17582520

SAQRANE, S., EL GHAZALI, I., OUDRA, B., BOUARAB, L. and VASCONCELOS, V., 2008. Effects of cyanobacteria producing microcystins on seed germination and seedling growth of several agricultural plants. Journal of Environmental Science and Health. Part. B, Pesticides, Food Contaminants, and Agricultural Wastes, vol. 43, no. 5, p. 443-451. http://dx.doi. org/10.1080/03601230802062307. PMid:18576226

SAQRANE, S., OUAHID, Y., EL GHAZALI, I., OUDRA, B., BOUARAB, L. and DEL CAMPO, FF., 2009. Physiological changes in Triticum durum, Zea mays, Pisum sativum and Lens esculenta cultivars, caused by irrigation with water contaminated with microcystins: a laboratory experimental approach. Toxicon, vol. 53, no. 7-8, p. 786-796. http://dx.doi.org/10.1016/j.toxicon.2009.01.028. PMid:19470329

SIEGL, G., MACKINTOSH, C. and STITT, M., 1990. Sucrosephosphate synthase is dephosphorylated by protein phosphatase $2 \mathrm{~A}$ in spinach leaves. Evidence from the effects of okadaic acid and microcystin. FEBS Letters, vol. 270, no. 1-2, p. 198-202. http://dx.doi.org/10.1016/0014-5793(90)81267-R. PMid:2171989

SIVONEN, K. and JONES, G., 1999. Toxic cyanobacteria in water: A guide to the Public Health Consequences, Monitoring and Management. In CHORUS, I. and BARTRAM, J. (Eds.). Cyanobacterial toxins. London: E \& FN Spon. p. 41-111.

STÜVEN, J. and PFLUGMACHER, S., 2007. Antioxidative stress response of Lepidium sativum due to exposure to cyanobacterial secondary metabolites. Toxicon, vol. 50, no. 1, p. 85-93. http:// dx.doi.org/10.1016/j.toxicon.2007.02.019. PMid:17434197

WANG, Z., XIAO, B., SONG, L., WU, X., ZHANG, J. and WANG, C., 2011. Effects of microcystin-LR, linear alkylbenzene sulfonate and their mixture on lettuce (Lactuca sativa L.) seeds and seedlings. Ecotoxicology, vol. 20, no. 4, p. 803-814. http:// dx.doi.org/10.1007/s10646-011-0632-2. PMid:21409590

WEHR, JD. and SHEATH, RG., 2003. Freshwater Algae of North America: Ecology and Classification. 2nd ed. USA: Academic Press. 918 p. 
WICKSTROM, ML., KHAN, SA., HASCHEK, WM., WYMAN, JF., ERIKSSON, JE., SCHAEFFER, DJ. and BEASLEY, VR., 1995. Alterations in microtubules, intermediate filaments, and microfilaments induced by microcystin-LR in cultured cells. Toxicologic Pathology, vol. 23, no. 3, p. 326-337. http://dx.doi. org/10.1177/019262339502300309. PMid:7659955

World Health Organization - WHO, 1998. Cyanobacterial toxins: microcystin-LR guidelines for drinking-water quality. Geneva. p. 95-110.

WOOD, SA., HEATH, MW., HOLLAND, PT., MUNDAY, R., MCGREGOR, GB. and RYAN, KG., 2010. Identification of a benthic microcystin-producing filamentous cyanobacterium (Oscillatoriales) associated with a dog poisoning in New Zealand. Toxicon, vol. 55, no. 4, p. 897-903. http://dx.doi.org/10.1016/j. toxicon.2009.12.019. PMid:20043936

XUE, Y., LI, Y., YI, N. and LI, H., 2010. Investigations into the effects of microcystin-LR on the growth and antioxidant enzymes in Chinese cabbage and rape. Bioinformatics and Biomedical Engineering, vol. 1, p. 1-5.
YAMASAKI, S., 1993. Probable effects of algal bloom on the growth of Phragmites australis (Cav.) Trin. Ex Steud. Journal of Plant Research, vol. 106, no. 2, p. 113-120. http://dx.doi. org/10.1007/BF02344414.

YIN, L., HUANG, J., LI, D. and LIU, Y., 2005a. Microcystin-RR uptake and its effects on the growth of submerged macrophyte Vallisneria natans (lour.) hara. Environmental Toxicology, vol. 20, no. 3, p. 308-313. http://dx.doi.org/10.1002/tox.20122. PMid: 15892062

YIN, L., HUANG, J., HUANG, W., LI, D. and LIU, Y., 2005 b. Responses of antioxidant system in Arabidopsis thaliana suspension cells to the toxicity of microcystin-RR. Toxicon, vol. 46, no. 8 , p. 859-864. http://dx.doi.org/10.1016/j.toxicon.2004.12.025. PMid:16269166

ZEGURA, B., GAJSKI, G., STRASER, A., GARAJ-VRHOVAC, V. and FILIPIČ, M., 2011. Microcystin-LR induced DNA damage in human peripheral blood lymphocytes. Mutation Research, vol. 726, no. 2, p. 116-122. http://dx.doi.org/10.1016/j. mrgentox.2011.10.002. PMid:22001196 
http://dx.doi.org/10.1590/1519-6984.er7502

\section{Erratum}

Due to a desktop publishing error in the article "Phytotoxicity associated to microcystins: a review" published in volume 74, issue 4, p. 753-760, 2014, with the exception of the page 755, column 1, paragraph 6, line 2 (equivalent to 0.008 to $4 \mathrm{mg} \mathrm{L}-1$ ) in all the text where you read "mg", should read " $\mu \mathrm{g}$ ". 